TAPROBANICA, ISSN 1800-427X. November, 2021. Vol. 10, No. 02: pp. 133-134.

(C) Research Center for Climate Change and Department of Biology, Faculty of Mathematics \& Natural Sciences, University of Indonesia, Depok 16424, INDONESIA.

http://www.taprobanica.org

https://doi.org/10.47605/tapro.v10i2.266

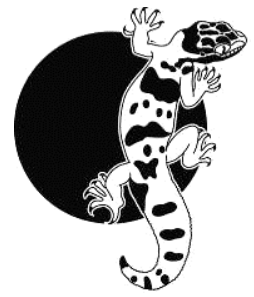

\section{A breeding record of the brown hawk owl (Ninox scutulata) in Assam, India}

The brown hawk owl, Ninox scutulata (Raffles, $1822)$ is a common, medium sized bird of prey on the Indian subcontinent (Ali \& Ripley 1983, Rasmussen \& Anderton 2012) and listed as of least concern (Bird Life 2016). Its distribution range extends up to eastern Siberia, Japan, the Andmans, the Malay Peninsula, the Great and Lesser Sundas, Wallacea, Taiwan, the Philippines and Australia. There are 11 well documented subspecies across this wide distribution (König et al. 1999).

A pair of brown hawk owls was observed nesting on a Dillenia indica tree (Family Dilleniaceae), in Guwahati, Kamrup District, Assam, India. The nest was in a cavity at a height of about $4 \mathrm{~m}$. The tree was about $14 \mathrm{~m}$ tall and the main trunk was about $7 \mathrm{~m}$ in girth. It had a dense canopy with its large elliptical leaves. During the year 2016, the owl's presence was noted by their calls in the evening and subsequent frequent visual encounters were made. The owls were observed with binoculars, photographed with a DSLR camera and calls were recorded with a voice recorder. Four breeding attempts were recorded from 2016 to 2019. Most of the photographs were taken during daytime without a flash (Barve et al. 2020a,b). The owls shared the nesting tree with a jungle myna, Acridotheres fuscus. The myna's nest was about $1 \mathrm{~m}$ away from the owls' nest. The owls shared their territory with two other owl species, collared scops owl, Otus bakkamoena and Asian barred owlet, Glaucidium cuculoides which called and hunted almost during the same time as the brown hawk owl. There was hardly any human disturbance to the breeding birds recorded during these observations.

There were 70 observations of the owls recorded opportunistically: 11 observations (2531 May 2016), 32 (13 March-15 May 2017), 23 (1 February-29 April 2018), and 4 (8 December
2018-27 January 2019). The female was slightly larger than the male. On 30 occasions, they were noted resting on a perch. The calls were recorded on 18 occasions, and on 22 occasions feeding and hunting were documented. The birds were seen resting from 0530 to $1730 \mathrm{~h}$. They had a preferred perch at about seven meters from the ground close to their nest cavity. Mostly they perched singly $(n=28)$ and rarely in pairs $(n=2)$. They were active during daylight hours only twice. Once they fed on a bird from 1105 to $1120 \mathrm{~h}$ (Fig. 1) and on the other occasion they showed aggression to an unknown intruder. The owls gave first call at about $1730 \mathrm{~h}$ with 11 to 25 hoots; calls were made by both, male and female. After that the pair called irregularly throughout the night, until $0530 \mathrm{~h}$. On rare occasions, they fed their young with birds. Both parents were seen feeding insects and geckos to their nestlings especially during 2016. Both birds were indifferent to my presence and would hunt, feed and carry prey items to the nest in my presence. It appeared that they took advantage of insects and geckos attracted to nearby light.

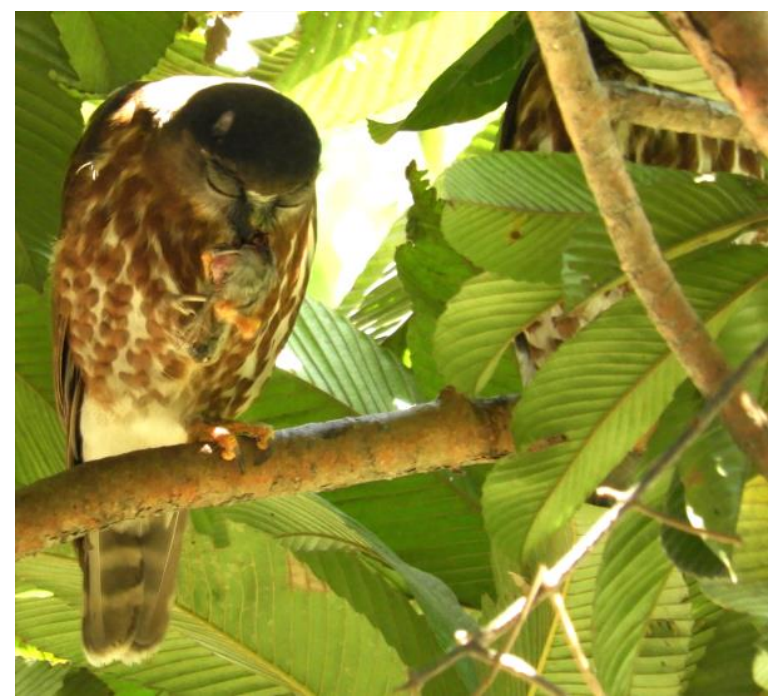

Figure 1. A male Brown hawk owl feeds on a bird while a female is perched next to it

In the year 2016, the owls raised three nestlings that fledged on 28 May. During 2017, 
one young bird fledged on 15 May. During 2018, the pair occupied the nest from 1 February and nesting activity continued until 29 April with two eggs confirmed in the nest. Out of the two, only one chick fledged. During the fourth season, the nest was occupied early in December 2018 and continued to be occupied until end of January 2019, after which it was abandoned by the pair. The nest was not occupied during 2020 . It was interesting to note that there were three pairs of owls within a $2 \mathrm{~km}$ radius around the nest under observation.

The brown hawk owl is known to lay 2 to 5 eggs, in North India during June and July. Incubation takes about 24 days and fledging takes place 24-27 days after hatching. In Assam, it is known to prefer woodland habitats near human settlements (König et al. 1999). del Hoyo et al. (1999) stated the breeding season is from March to June. However, the present study suggests a breeding season from February to May. In a similar observational study in Melbourne, Australia, a pair of Powerful Owl, Ninox strenua raised 1 or 2 young for 4 years and was recorded as sensitive to the increasing disturbance due to urbanisation (Cooke et al. 2002). In the current study, breeding performance of the brown hawk owl declined over the four year study period, probably due to ageing of the pair and/or food limitations due to increasing effects of urbanization.

\section{Literature cited}

Ali, S. and S.D. Ripley (1983). Handbook of the birds of India and Pakistan together with those of Bangladesh, Nepal, Bhutan and Sri Lanka. Oxford University Press, Delhi: 737pp.

Barve, S., T.R.S. Raman, A. Datta, and G. Jathar (2020a). When and how to study the nesting biology of Indian birds: research needs, ethical considerations, and best practices. Indian Birds, 16(1): 1-9.
Barve, S., T.R.S. Raman, A. Datta, and G. Jathar (2020b). Draft guidelines for conducting research on the nesting biology of Indian birds. Indian Birds, 16(1): 10-11.

Bird Life International (2016). Ninox scutulata. The IUCN Red List of Threatened Species 2016:

e.T22725643A94898103. Downloaded on 02 August 2020.

Cooke, R., R. Wallis, and A. Webster (2002). Urbanisation and the ecology of powerful owls (Ninox strenua) in outer Melbourne, Victoria: 100-106 pp. In: Newton, I., R. Kavanagh, J. Oslen, and I. Taylor (eds.). Ecology and conservation of Owls. CSIRO Publishing, Australia.

del Hoyo, J., A. Elliott, and J. Sargatal (eds.) (1999). Handbook of the Birds of the World. Volume 5: Barn-owls to Hummingbirds. Lynx Edicions, Barcelona: 759pp.

König, C., F. Weick, and J.H. Becking (1999). Owls: A guide to the owls of the world $\left(1^{\text {st }}\right.$ edition). Robertsbridge, UK: 462pp.

Rasmussen, P.C. and J.C. Anderton (2012). Birds of South Asia: the Ripley guide ( $2^{\text {nd }}$ edition). Smithsonian Institution and Lynx Editions, Washington D.C. and Barcelona (2 volumes): 378pp, 683pp.

Submitted: 23 Mar. 2021, Accepted: 11 Sep. 2021 Section Editor: S.M. Henkanaththegedara

S.P. Ranade

Vulture Conservation Breeding Centre, Belguri Village, Rani, Kamrup District, Assam 781 131, India E-mail: s.ranade@bnhs.org 